\title{
The 2014 European Parliamentary Elections: Emerging signs of a shift from 'solidarity' to 'politicization' at the EU-level
}

\begin{abstract}
Party political forces in the form of the European Political Groups (EPGs) and the Europarties populate the parliamentary and extra-parliamentary landscape at the EU-level. In so doing, they remind us that the European Parliament (EP) is both a legislative and representative body that needs to be renewed every five years. In its legislative guise, where no one political group commands a majority, some form of crossparty solidarity between the political mainstream has always been essential. At the representative level, however, the resonance of this setup is coming under greater scrutiny. First, because of the intensifying electoral struggle between the forces associated with the political mainstream and the various shades of Euroscepticism which revel in their status as political outsiders. Second, because of the growing belief that such cross-party solidarity is undermining the potential of mainstream party politics, at the EU-level, to develop linkages with European voters. In a partial response to this dilemma, the mainstream engineered the inauguration of the Spitzenkandidaten (i.e. the 'indirect' election of the President of the European Commission) as part of the 2014 European elections. As the guardians of this process, the Europarties would be responsible for selecting a 'leading candidate' - a Spitzenkandidat. She/ he would go on to become the 'face' of their corresponding election
\end{abstract}


campaign. This, they hoped would help to revitalize democratic participation and raise turnout. Despite its limitations, the Spitzenkandidaten innovation represents an important milestone in the direction of politicizing the European elections and the wider European project. Whether or not this is the start of a reform trajectory that takes the process of politicization even further, by creating a context conducive to the strengthening of the ideational and organizational nature of party politics at the EU-level, remains to be seen.

'Neither party members nor electors showed any enthusiasm for these elections' (Dutch Labour Party Report, 1979)

\subsection{Introductory Remarks}

European elections remind us that the European Parliament (EP) is not just a legislative body; it also has a representative face that needs to be renewed every five years. The parliamentary and extra-parliamentary landscape where this plays out is populated by EU-level party political forces in the form of the Europarties and European Parliamentary Groups (EPGs) - both of which are constituted by national member parties. This time round, in the midst of a six-year economic crisis, the normative battle between the forces of the mainstream and the various shades of Euroscepticism has intensified dramatically. While the mainstream has been successful in ensuring the inauguration of the first indirectly elected' Commission President, their Eurosceptic opponents on the right have become increasingly assertive and successful in raising their electoral profile to approximately 21.43 percent of the seats in the EP (22.62 percent if we include the small percentage of 'Others'). This figure rises to approximately 29.55 percent if the European United Left/Nordic Green Left (GUE/NGL), a radical/far-left non-mainstream force, is also included. 
The 2014 European Parliamentary Elections: Emerging signs of a shift from 'solidarity' to 'politicization' at the EU-level

(Day)

Under such circumstances, it remains doubtful if the fog of self-doubt that has descended over the wider European project, in recent years, will be lifted in the short-term. It, of course, was never meant to be like this. Remember it was not that long ago that the political, economic and social model of the EU, as well as its cultural underpinnings, were being proclaimed as a potential role model for the $21^{\text {st }}$ Century. Yet, as the impact of the post-Lehman's shock sovereign-debt crisis drifted across the Continent, a sort of existential crisis took hold. In 2009, the eminent historian Timothy Garton-Ash cautioned that ' $[\mathrm{t}]$ he forces of integration and disintegration, of European solidarity and national egoism, the centripetal and the centrifugal, are firmly balanced.' Four years later, Joschka Fischer lamented ' $\cdots$ trust is giving way to mistrust, solidarity is succumbing to ancient prejudices (and even new hatreds between the poor south and the rich north), and compromise is being overwhelmed by diktat.' The implication that can be drawn from such musings is that as solidarity, described as ' $\cdots$ a motif of European integration, wanes, so the sustainability of the European project becomes increasingly precarious.

At the parliamentary level, the notion of solidarity (primarily in the form of cross-party co-operation between the mainstream EPGs) has been at the heart of the European Parliament's legislative operations. The revered status afforded to solidarity, as a necessary and sufficient ingredient for the promotion of the European project, meant that, until recently, it was essentially taken for granted and shielded from debate. Yet, if we interpret the insights of Julian Priestley (former SecretaryGeneral of the European Parliament) correctly, then there would appear to be an intriguing dilemma at play at the heart of the European parliamentary system. From Priestley's perspective '… cross-party collaboration which has been so necessary to take the Union forward and to enhance the role and influence of the Parliament $\cdots$ is now suffocating political vitality and impeding any connection between the European 
politicians and the European citizens.' This translates into a situation where the methods associated with the ability of the mainstream EPGs to perform their role as legislators (where none of the Party Groups commands a majority thereby necessitating an atmosphere where solidarity is conducive to getting things done) are simultaneously deemed responsible for undermining the appeal of mainstream party politics at the EU-level in the eyes of the electorate, and in turn, that of the standing of the EP as a representative arena. This has provided various Eurosceptic forces with the ammunition to revel in their status as political outsiders/anti-establishment forces. From here they proclaim that the parliamentary mainstream is operating in an anti-democratic/cartel-like manner and, in its extra-parliamentary guise, that the mainstream parties are essentially indistinguishable from each other.

It was within this volatile atmosphere that the events of the 2014 (May 22 $2^{\text {nd }}-25^{\text {th }}$ ) election would unfold. This would also be an election that acted as a surrogate for the arrival of a new innovation - the Spitzenkandidaten. As the guardians of this process, the Europarties would be responsible for selecting a 'leading candidate' - a Spitzenkandidat. She/he would go on to become the 'face' of their corresponding election campaign. From here, it was anticipated that this would translate into the propagation of a more ideologically charged atmosphere by the Europarty candidates i.e. a process of politicization. This, in turn, would provide voters with the means to differentiate more effectively between the competing mainstream forces and, in so doing, act as an antidote to the 'suffocating' impact of solidarity implied by Priestley. Subsequently, the candidate from the winning party would be expected to become the President of the European Commission - at least according to the interpretation of the relevant passages of the Lisbon Treaty by advocates of the initiative. By tethering the selection of the Commission President to the outcome of the European election, proponents also believed that this would herald an important step for the revitalization 
The 2014 European Parliamentary Elections: Emerging signs

of a shift from 'solidarity' to 'politicization' at the EU-level

(Day)

of democracy at the EU-level. Opponents dismissed it out of hand. From their perspective, it was a futile exercise that did not merit their involvement.

Taking into account these developments, the goal of this article will be to explore some of the events surrounding the process and outcome of the 2014 European election. Underpinning the paper is the use of a simple dichotomy that focuses attention on the political struggle between mainstream and Eurosceptic political forces at the EU-level. Although this provides a useful way of dealing with the election, its simplicity does have certain limitations, especially when one begins to analyse party politics at the national level where the boundaries between the two positions can become increasingly fuzzy. By focusing on events through the eyes of the Europarties and the EPGs, however the demarcation lines between the two contrasting positions appears much more distinct. It should also be noted that, in both cases, the moniker 'mainstream' and 'Eurosceptic' are sometimes tied to their Europarty handle and sometimes to their EPG, depending on the situation, which can be a little confusing. In terms of its application, the use of the term 'mainstream' is usually applied to the following Europarties and their corresponding EPGs: the European People's Party (EPP and the EPP Group), Party of European Socialists (PES and the Socialists \& Democrats Group), the Alliance of Liberals and Democrats for EuropeParty (ALDE and the ALDE-Group), and the European Greens (EG and the European Greens/European Free Alliance Group). In essence, the mainstream, as the dominant tendency, is viewed as generally supportive of the integration process (albeit with varying levels of enthusiasm depending upon national traditions and prevailing political conditions), the continuing use of the Community Method and the principles of subsidiarity.

In terms of the various Eurosceptic forces, at the parliamentary and extra-parliamentary level, we can point to the European Conservatives 
and Reformists (and its Europarty the Alliance of European Conservatives and Reformists - AECR) and the Europe of Freedom and Direct Democracy (EFDD). At the end of 2014, leading member parties of the EFDD successfully registered a new Europarty called the Alliance for Direct Democracy in Europe (ADDE). A number of the various farright/extremist parliamentary forces whose MEPs sit as Non-Inscrits have also successfully registered themselves as a Europarty. This includes the European Alliance of Freedom (EAF - a party composed of individual parliamentarians rather than national political parties) and the Alliance of European National Movements (AENM). In late 2014, Marine Le Pen left the EAF. Under her leadership, the French National Front (FN) has been at the forefront of establishing the Movement for a Europe of Nations and Freedom (MENF) as an EU-level political party. Taken as a whole, Eurosceptics incorporate a rather eclectic mix of views as part of their opposition to the EU. Economically this ranges from support for entrepreneurialism and the free market that is undermined by the EU through to opposing the economic forces associated with globalization that is promoted by the EU. There is also a great deal of emphasis on what is labelled 'identity politics' which includes a disdain for multi-culturalism and emphasises the virtues of a national based cultural conservatism. Locating the GUE/NGL Group, many of whose member parties are associated with the Party of the European Left (PEL), within the mainstream/Eurosceptic dichotomy is a little less straightforward compared to the forces on the right due to its attitude toward the idea of a 'European Union'. In his acceptance speech on becoming the Spitzenkandidat of the PEL, for example, Alexis Tsipras talked about representing another type of Europe that differed from what the party believes to be an austerity and neo-liberal driven project supported by the mainstream. He wanted a 'Europe of social cohesion, peace, solidarity, and democracy without boundaries. The future of the European project, from the perspective of many of its member par- 
The 2014 European Parliamentary Elections: Emerging signs

of a shift from 'solidarity' to 'politicization' at the EU-level

(Day)

ties, could also include the continuing use of the Euro.

In light of the above, this article will proceed in the following manner. To begin with, Section 2 will briefly recall the contested origins of the European Parliament (EP) before drawing attention to the apparent disjuncture between the success of its legislative role and its standing as a representative vehicle. Section 3 will focus on the process surrounding the Spitzenkandidaten and provide an overview of the 2014 election results. In the wake of the continuing challenges facing the EP and the political mainstream, following the election, Section 4 will discuss the suggestion that a greater emphasis on the continued development and politicization of the Europarties could elevate the representative face and standing of the EP. I will then make some brief concluding remarks.

\subsection{Contrasting Fortunes-the European Parliament as a Legislative Arena and Representative Vehicle}

Even before the seventy-eight, appointed deputies, took the unprecedented decision to take their seats as ideological formations, rather than as national blocs, in June 1953 there were major disagreements about the purpose of the Common Assembly (which would eventually morph into the European Parliament). As Goetze and Rittberger inform us, the negotiations surrounding the Schuman Plan (1948-1951) ' $\cdots$ mark[ed] only the prelude to a battle between proponents and critics of the EP about the role it should play in the Community, the powers it should possess and the legitimacy upon which these powers supposedly rest.' In addition to such structural disputes, questions about its operational role as a legislature (both in its appointed and elected incarnation) and issues surrounding its political make-up have been constant bedfellows. Prior to the first direct election in 1979, for example, anti-system/Eurosceptic parties remained absent from the Chamber. For Stein, writing in 1959, such an exclusion by national parliaments of ' $\cdots$ the Communists, Pou- 
jadists, and Neo-Fascists from their Strasbourg contingents $\cdots$ diminish[ed] the representative character of the Assembly.' Holding back such forces proved to be futile once direct elections commenced. Following a 62 percent turnout, the three largest mainstream parliamentary groups - the Christian Democrats, Liberals and Socialists - accounted for just 63 percent of the seats. Reif and Schmitt concluded that the election should be classified as a 'second-order' election - a term that has been liberally applied to every subsequent electoral contest. From their perspective, the key characteristics of this type of election include lower levels of participation; brighter prospects for small and new parties; [and a tendency for] Government parties [to] lose'.

Whatever the outcome of the elections, of course, the European Parliament still has to play its dual role, as a law-making forum (though not as an initiator of those laws) and as a representative arena for ideological groupings that must present themselves to the electorate every five years. Concerning its legislative role, there is no doubt that over time this has changed beyond all recognition since it was first imbued with supervisory powers back in the 1950s. Today, it commands an extensive array of legislative powers and governance roles that have banished all of the previous chatter of it being merely a 'talking shop'. Operationally, Richard Corbett (at the time an ex-MEP), in a 2013 letter to the European Voice, also stressed the Parliament's rather unique working culture that facilitates cross-party support (solidarity) to pass legislative measures. From his perspective:

'It is not a parliament with a 'governing majority' automatically supporting the executive: majorities have to be built by explanation, persuasion and negotiation (what parliaments were supposed to be about before many of them became rubber-stamps for the executive).

As a representative vehicle for European citizens, however, the Parliament has struggled to attain a comparable standing. In the run-up to 
The 2014 European Parliamentary Elections: Emerging signs of a shift from 'solidarity' to 'politicization' at the EU-level

(Day)

the first direct election, for example, Helen Wallace was of the opinion that '[t] he lack of popular excitement at the prospect of direct elections [amounted to] evidence of the very detachment of the EC from a mass base.' Despite her expectation that this situation would rectify itself in due course, turnout has continued to decline at each subsequent election. Indeed, comments at the time, which would not be out of place 35-years later, from some of the centre-left parties, are illustrative of the disappointment. The French Socialist Party, for example, spoke of 'Europe being too remote from its peoples' and 'exceptional levels of abstentions' while the Luxembourg Socialist Workers lamented the "minimal voter interest'.

Contributing to this representative weakness is the continuing underdevelopment of the extra-parliamentary Europarties. Having originated in the mid-to-late 1970s it was not until the 1993 Maastricht Treaty that they received legal recognition. According to Article 138a EC: 'Political parties at European level are important as a factor for integration within the Union. They contribute to forming a European awareness and to expressing the political will of the citizens of the Union.' Renumbered Article 191 EC, as part of the Nice Treaty, a second paragraph was added that provided the motor for the introduction of a Party Regulation and accompanying funding. This came to fruition in 2004 with funds being distributed to those parties deemed to have satisfied certain criteria that formed the backbone of the Regulation - not least a compliance with specific European values. A 2007 amendment finally allowed for a part of those funds to be used for the purposes of electioneering. With a new funding regime in place it was hoped that this would help to enhance the ability of the Europarties to fulfil the role set out for them in a slightly slimmed down party article given that the words 'are important as a factor for integration within the Union', from Article 191, were dropped. The new Article 10(4) TEU reads: 'Political parties at European level contribute to forming European political awareness and 
to expressing the will of citizens of the Union'. Although 10(4) remains more aspirational than actual, in 2013-14 there was a significant shift in the role played by the Europarties as they took centre-stage in the aforementioned Spitzenkandidaten process.

\subsection{The Spitzenkandidaten Process and the 2014 European Election}

The backstory of the Spitzenkandidaten initiative spans more than a decade of debate about how it might be possible to link the position of Commission President with the European elections. Proponents would have to wait until the Lisbon Treaty and the opening words of Article 17(7) TEU - 'Taking into account the elections to the European Parliament - combined with Declaration 11, were in place. This would provide the green light to turn the idea into a political reality (see table one below). Although supportive of, and hopeful about, the introduction of the Spitzenkandidaten procedure, Joseph Weiler offered sage advice in stressing the need for caution:

'The ideological politicisation of the Commission and, in its wake, the politicisation of Europe as a whole, is an entirely new ball game. It would require not only a huge shift in the institutional culture of the institutions of the EU, but an adaptation of the political culture of the polity as a whole with not insignificant trade-offs.'

A year before the European Parliamentary election, the Commission sought to stress the significance of the Spitzenkandidaten innovation as part of an attempt to raise the profile of the election and " $[\mathrm{t}] \mathrm{o}$ strengthen the link between citizens and the $\mathrm{EU}$ and to turn European elections into a real European endeavour'. Between November 2013 and March 2014, five of the Europarties took it upon themselves to select a candidate (as shown in table two). The PES, ALDE and PEL chose a candidate without an electoral contest while the EPP completed the line-up following an overnight intra-party contest during its Party Con- 
The 2014 European Parliamentary Elections: Emerging signs of a shift from 'solidarity' to 'politicization' at the EU-level

TABLE ONE: Article 17(7) and Declaration 11

\begin{tabular}{|c|c|}
\hline Article $17(7)$ TEU & Declaration 11 on Article $17(6)$ and $17(7)$ \\
\hline $\begin{array}{l}\text { Taking into account the elections } \\
\text { to the European Parliament and } \\
\text { after having held the appropriate } \\
\text { consultations, the European Coun- } \\
\text { cil, acting by a qualified majori- } \\
\text { ty, shall propose to the European } \\
\text { Parliament a candidate for Presi- } \\
\text { dent of the Commission. This } \\
\text { candidate shall be elected by the } \\
\text { European Parliament by a major- } \\
\text { ity of its component members } \cdots \text {. }\end{array}$ & $\begin{array}{l}\text { The Conference considers that, in accordance with the } \\
\text { provisions of the Treaties, the European Parliament and } \\
\text { the European Council are jointly responsible for the } \\
\text { smooth running of the process leading to the election } \\
\text { of the President of the European Commission. Prior to } \\
\text { the decision of the European Council, representatives of } \\
\text { the European Parliament and of the European Council } \\
\text { will thus conduct the necessary consultations in the } \\
\text { framework deemed the most appropriate. These consul- } \\
\text { tations will focus on the backgrounds of the candidates } \\
\text { for President of the Commission, taking account of the } \\
\text { elections to the European Parliament, in accordance } \\
\text { with the first subparagraph of Article } 17(7) \cdots\end{array}$ \\
\hline
\end{tabular}

Source: Consolidated Version of the Treaty on European Union (Lisbon Treaty). This can be found at: http://eur-lex.europa.eu/legalcontent/EN/TXT/PDF/?uri=CELEX: $12012 \mathrm{M} / \mathrm{TXT} \&$ from=EN.

TABLE TWO: Europarty Spitzenkandidat ('Leading Candidate') Nominees

\begin{tabular}{|l|l|}
\hline Europarty & Name of Candidate(s) \\
\hline European Peoples Party (EPP) & Jean-Claude Juncker \\
\hline Party of European Socialists (PES) & Martin Schulz \\
\hline Alliance of Liberals and Democrats for Europe (ALDE-Party) & Guy Verhofstadt \\
\hline European Greens (EG) & José Bové \& Ska Keller \\
\hline Party of European Left (PEL) & Alexis Tsipras \\
\hline
\end{tabular}

Source: Compiled by the author.

gress in March 2014. The European Greens were the only party to engage in a real substantive electoral process where voters were asked to select two candidates from a list of four elected in an on-line open primary. In the end, 22,676 voters participated; whether that amounts to a success or a failure is a matter of opinion.

Embedded within the Spitzenkandidaten process was the expectation that such a contest would provide voters with an opportunity to partici- 
pate in an authentic EU-wide campaign as the 'leading candidates' undertook whistle-stop tours and engaged in multi-language debates centred around the common manifestoes published by the Europarties. This, it was believed, would help to raise turnout from its 2009 historic low. The sense of anticipation and expectation that was coming from the Europarties, however, was a far-cry from some of the general media coverage. A European Voice editorial commenting on the candidates and potential candidates as at the beginning of February 2014, for example, did not mince its words: 'All this smacks of an EU still dominated by the founding six states, by men, and by old ideas.'

\subsection{The Results}

During a four-day window in late May, voters across the EU had the chance to pass judgment on their European representatives. As the results were being called, leading figures from the mainstream clung to the news that turnout was up. At the time, the official estimate put the figure at 43.09 percent - an increase of 0.9 percent compared to 2009. A couple of months later though the final figure would be revised downwards to 42.53 percent, which actually meant a new record low. The morning after the election, the headlines were not dominated by the ability of the political mainstream to secure around 70 percent of the seats but rather the increase in support for their Eurosceptic foes. In particular, the success of the French National Front (FN - which secured 24 seats out of 74) and the United Kingdom Independence Party (UKIP that increased its 2009 tally of 13 seats to 24) and smiling pictures of their charismatic leaders - Marine Le Pen and Nigel Farage. Eurosceptics would also top the poll in Denmark with 4 of the 13 seats going to the Danish People's Party. In the case of Greece, which remained ground-zero in terms of the ongoing social consequences of the sovereign debt crisis, disgruntled voters turned away from the main- 
The 2014 European Parliamentary Elections: Emerging signs of a shift from 'solidarity' to 'politicization' at the EU-level

(Day)

stream as it was squeezed by both the far-left and far-right. The farleft Syriza (Coalition of the Radical Left) which is a member party of the PEL and the GUE/NGL Parliamentary Group, topped the polls with 6 of the 21 seats. The far-right Golden Dawn also increased the level of its support from 0.5 percent of the vote in 2009 to 9.4 percent, taking 3 seats. In their national context, of course, many of these results were dramatic but in a wider European context, there were also plenty of examples of Eurosceptic forces failing to make any inroads. At the election count, the Europe of Freedom and Democracy Group (shortly afterwards renamed the Europe of Freedom and Direct Democracy Group EFDD), for example, had representatives in only 7 of the 28 member states while the European Conservatives and Reformists (ECR) had no representatives in 12 member states. There were four member states (Romania, Malta, Luxembourg and Estonia) where all of the seats went to member parties from the four mainstream EPGs.

In terms of the mainstream, the largest loss of seats was actually incurred by the overall winner of the election, the EPP. Prior to the dissolution of the 2009-2014 Parliament, they held 275 seats. In the new Chamber, they would hold 221. Politically, though, it was the reduction in support for the Liberals that was particularly noticeable as it resulted in them losing the coveted 'third-party' status. Their decline was driven by the electoral meltdown endured by the Liberal Democrats in the UK (which lost 10 of the 11 seats that it had won in 2009) and the Free Democrats in Germany that fell from 12 to 3 seats. After the elections, the Group also suffered the defection of one of its member parties from Romania, which decided to join the EPP. Months later at their Party Congress in Lisbon (November 2014), the ALDE-Party launched a period of soul searching under the title 'Reclaiming Liberalism'. In the case of the political forces associated with the centre-left, early opinion polls in February and March of 2014 were predicting that they would win the elections. It was not to be. Commenting on the fi- 
『日本 $\mathrm{EU}$ 学会年報』第35号, 平成 27 年 4 月

TABLE THREE: European Parliamentary Groups (EPGs) and number of seats held before and after the 2014 election

\begin{tabular}{|c|c|c|c|}
\hline $\begin{array}{l}\text { European Parliamentary } \\
\text { Groups 2009-2014 (in } \\
\text { order of size) }\end{array}$ & $\begin{array}{l}\text { Number of Seats } \\
\text { in 2009. The figure } \\
\text { in brackets indi- } \\
\text { cates the number } \\
\text { of seats held prior } \\
\text { to the dissolution } \\
\text { of the EP in } 2014\end{array}$ & $\begin{array}{l}\text { European Parliamentary } \\
\text { Groups 2014-2019 (in or- } \\
\text { der of size) }\end{array}$ & $\begin{array}{l}\text { a) Number of } \\
\text { Seats at the elec- } \\
\text { tion count. b) } \\
\text { the final distribu- } \\
\text { tion of seats as } \\
\text { at July } 1,2014\end{array}$ \\
\hline $\begin{array}{l}\text { EPP: Group of the Eu- } \\
\text { ropean People's Party } \\
\text { (Christian Democrats) }\end{array}$ & $265(275)$ & $\begin{array}{l}\text { EPP: Group of the Euro- } \\
\text { pean People's Party } \\
\text { (Christian Democrats) }\end{array}$ & $\begin{array}{l}\text { a ) } 213(28.36 \%) \\
\text { b ) } 221(29.42 \%)\end{array}$ \\
\hline $\begin{array}{l}\text { S\&D: Group of the } \\
\text { Progressive Alliance of } \\
\text { Socialists and Demo- } \\
\text { crats in the European } \\
\text { Parliament }\end{array}$ & $184(195)$ & $\begin{array}{l}\text { S\&D: Group of the Pro- } \\
\text { gressive Alliance of Social- } \\
\text { ists and Democrats in the } \\
\text { European Parliament }\end{array}$ & $\begin{array}{l}\text { a ) } 190(25.29 \%) \\
\text { b) } 191(25.43 \%)\end{array}$ \\
\hline $\begin{array}{l}\text { ALDE/ADLE: Group of } \\
\text { the Alliance of Liberals } \\
\text { and Democrats for Eu- } \\
\text { rope }\end{array}$ & $84(85)$ & $\begin{array}{l}\text { ECR: European Conserva- } \\
\text { tives and Reformists } \\
\text { Group }\end{array}$ & $\begin{array}{l}\text { a ) } 46(6.12 \%) \\
\text { b ) } 70(9.32 \%)\end{array}$ \\
\hline $\begin{array}{l}\text { GREENS/EFA: Group } \\
\text { of the Greens/European } \\
\text { Free Alliance }\end{array}$ & $55(58)$ & $\begin{array}{l}\text { ALDE/ADLE: Group of } \\
\text { the Alliance of Liberals } \\
\text { and Democrats for Europe }\end{array}$ & $\begin{array}{l}\text { a) } 64(8.56 \%) \\
\text { b) } 67(8.92 \%)\end{array}$ \\
\hline $\begin{array}{l}\text { ECR: European Conser- } \\
\text { vatives and Reformists } \\
\text { Group }\end{array}$ & $54(56)$ & $\begin{array}{l}\text { GUE/NGL: Confederal } \\
\text { Group of the European } \\
\text { United Left-Nordic Green } \\
\text { Left }\end{array}$ & $\begin{array}{l}\text { a ) } 42(5.59 \%) \\
\text { b ) } 52(6.92 \%)\end{array}$ \\
\hline $\begin{array}{l}\text { GUE/NGL: Confederal } \\
\text { Group of the European } \\
\text { United Left-Nordic } \\
\text { Green Left }\end{array}$ & $35(35)$ & $\begin{array}{l}\text { GREENS/EFA: Group of } \\
\text { the Greens/European Free } \\
\text { Alliance }\end{array}$ & $\begin{array}{l}\text { a) } 53(7.05 \%) \\
\text { b) } 50(6.65 \%)\end{array}$ \\
\hline $\begin{array}{l}\text { EFD: Europe of Free- } \\
\text { dom and Democracy } \\
\text { Group }\end{array}$ & $32(33)$ & $\begin{array}{l}\text { EFD: Europe of Freedom } \\
\text { and Direct Democracy } \\
\text { Group }\end{array}$ & $\begin{array}{l}\text { a ) } 38(5.05 \%) \\
\text { b ) } 48(6.39 \%)\end{array}$ \\
\hline NA: Non-attached & $27(29)$ & NA: Non-attached & $\begin{array}{l}\text { a ) } 41(5.45 \%) \\
\text { b ) } 43(5.72 \%)\end{array}$ \\
\hline Others & & & $\begin{array}{l}\text { a ) } 64(8.52 \%) \\
\text { b ) } 9(1.19 \%)\end{array}$ \\
\hline
\end{tabular}

Prior to the dissolution of the 2009-2014 Parliament, there were 766 MEPs up from the 736 at the time of the 2009 election. Because of the Lisbon Treaty, all post-2014 Parliaments will be capped at 751 seats.

Source: Figures taken from the European Parliament website. http://www.europarl.europa.eu/ elections2014-results/en/election-results-2014.html. Accessed July 2, 2014. Percentage calculations undertaken by the author. 
The 2014 European Parliamentary Elections: Emerging signs

of a shift from 'solidarity' to 'politicization' at the EU-level

(Day)

nal composition of the S\&D Group, Toby Vogel in the European Voice noted that: "The national make-up of the group has changed dramatically from the 2009-14 Parliament '.. More than half of the group's members are newcomers, and there is a significant number of women.'

Overall, the three oldest political families - the Christian Democrats, Liberals and Socialists - account for approximately 64 percent of the seats in the new parliament as outlined in table three. This is a position almost identical to the situation in 1979 and 1984 though some way off the 72 percent of the seats they secured in 2009. If we include the seats won by the Greens/EFA Group then the overall figure accumulated by the mainstream rises to a shade under 71 percent, leaving their opponents with just under 30 percent of the seats. The prevailing mood amongst the mainstream, though, was one of disappointment. As Martin Schulz, at the time Spitzenkandidat of the PES, put it, "[this] was a bad day for the European Union.

In the wake of the new Parliament's investiture a month after the election, the various shades of Euroscepticism have continued to experience mixed results. The ECR Group, dominated by the UK Conservatives (19 seats) and the Law and Justice Party from Poland (18 seats), having been joined, among others, by the Danish People's Party and the new Alternative for Germany (AfD which gained 7 of Germany's 96 seats), gained the coveted 'third-party' status. The pre-election promise of the far-right leader Marine Le Pen to form a Parliamentary Group has so far failed to materialize. Although she has been able to gather more than enough MEP's (25 are required), they do not constitute the necessary geographical reach (i.e. MEPs from at least $7 \mathrm{Mem}$ ber States), in part because Le Pen has ruled out working with Jobbik (Movement for a Better Hungary) and Golden Dawn (Greece). The second largest Eurosceptic force, the EFDD, dominated by UKIP, was bolstered by the 17 seats of Beppe Grillo's Five Star Movement (Italy). It continues, however, to remain vulnerable to intra-group fluidity. In 
October 2014, for example, the EFDD technically lost its group status following the defection of an MEP. This meant that it no longer had members from at least seven Member States. A few days later, with the arrival of a new MEP from Poland, the Group once again attained the necessary geographical criteria.

As the Spitzenkandidat of the EPP, which emerged with the most seats, Jean-Claude Juncker became the person that a majority of the Parliament insisted should become the choice of the European Council for Commission President designate. Even Alexis Tsipras, the leading candidate of the Party of the European Left (PEL), who spoke of "vigorous policy disagreements' with Juncker, was of the opinion that '[i]t is a moral obligation of the European Council to put forward the candidate who secured the leading position in the European election.' Throughout the rest of May and June, events would go on to generate considerable disagreement between proponents and opponents of the Spitzenkandidaten initiative as to whether Article 17(7)'s 'taking into account' amounted to an 'obligation' or merely a 'suggestion'. Opponents were also equating the mainstream's drive to secure compliance, with their interpretation, as an attempted 'power-grab' by the Parliament visà-vis the European Council. At this stage, the hesitancy of German Chancellor Angela Merkel towards Juncker (despite having backed him at the EPP Congress in March) gave UK Prime Minister David Cameron hope that he could orchestrate a campaign to block him. Cameron also appeared to have the Dutch and the Swedish Prime Ministers on his side at one stage. At the end of May, though, Merkel began to shift her position. According to Toby Vogel:

'Merkel was taken aback by a media campaign in Germany suggesting that it would be undemocratic if the lead candidate of the winning political party were not to become president of the Commission $\cdots$ she felt compelled to adjust her rhetoric and come out in favour of Juncker..' 
The 2014 European Parliamentary Elections: Emerging signs

of a shift from 'solidarity' to 'politicization' at the EU-level

(Day)

Cameron would continue to take his campaign all the way to June's European Council where Hungarian Prime Minister Viktor Orbán joined him in voting against Juncker's candidature. In contrast, twenty-six Member States voted to support Juncker - which amounted to 311 out of the 352 Council votes. In a bid to placate some of the concerns surrounding the whole process, particularly on the part of the UK government, the meeting attempted to secure itself some future leeway. In a section of the European Council Conclusions, entitled 'The Next Institutional Cycle', point 27 read: 'Once the new European Commission is effectively in place, the European Council will consider the process for the appointment of the President of the European Commission for the future, respecting the European Treaties.' It remains to be seen if any further action will actually be taken but given that the process now exists, it seems highly unlikely that it will be 'de-invented'. A few weeks later, the European Parliament would go on to elect Juncker. In the end, he secured 422 out of the 729 votes cast with 209 against and 67 abstentions. At the time, Juncker was quoted as saying 'Citizens are losing faith $\cdots \mathrm{We}$ are last chance Europe. Let's seize this chance.' Once again, he can be seen reflecting the rather negative mood that was prevailing across the mainstream.

\subsection{Politicizing the Mainstream}

During his Papal address to the EP (November 2014) Pope Francis argued that ' $\cdots$ there has been a growing mistrust of citizens toward institutions they regard as aloof, laying down rules that they view as insensitive to individual people's concerns..' Such words came at a time when representative democracy and political parties per se were facing an increasing set of challenges. In the case of the EU, therefore, it is the combination of falling turnout and all manner of arguments about the wider 'democratic deficit' that has rendered both the Parliament and 
transnational party politics vulnerable to critique from many different quarters. Oxford University academic Jan Zielonka, as part of his vision of a 'Europe of functional networks', for example, calls upon the European Parliament to ' $\cdots$ do what it does best through the auditing and monitoring of regulatory agencies, but abandoning all pretensions to act as a sovereign pan-European representative assembly.' A similarly dramatic intervention came from the former UK Foreign Secretary, Jack Straw, who went even further when he called for the Parliament's abolition on the grounds that it was simply unable to address the democratic deficit. His preferred alternative was an unelected/appointed interparliamentary assembly. Abolition also remains the ultimate goal of many of the Eurosceptic MEPs who wander the corridors of the Louise Weiss and Espace Léopold buildings.

Is there an alternative pathway where the European Parliament and party politics at the EU-level is part of the solution regarding issues of representation rather than part of the problem? For Follesdal and Hix:

'All that may be needed is for the political elites to make a commitment to open the door to more politicization of the EU agenda, for example via a battle for the Commission President, with governments and national and European parties backing different candidates and policy platforms.

Central to such a drive, though, is the form that such a politicization would take. Simply upping the existing pro-EU or anti-EU cleavage is unlikely to provide the mainstream with the necessary impetus to challenge their Eurosceptic rivals, as it would not mark enough of a departure from the status quo. If that is so, then the need to branch out into the sorts of policy areas that are central to people's day-to-day lives would appear necessary. Of course, some form of cross-party solidarity is still going to be required to pass legislation in a chamber where there is not likely to be a single EPG commanding a legislative majority. Nevertheless, being the largest group in the EP, combined 
The 2014 European Parliamentary Elections: Emerging signs of a shift from 'solidarity' to 'politicization' at the EU-level

(Day)

with having your leading candidate as Commission President certainly increases the likelihood of facilitating the push for a more distinct ideological flavour to the European project - the role of the European Council notwithstanding. Indeed, after having passed through the Spitzenkandidaten process, Jean-Claude Juncker, during his investiture speech at the Parliament uttered the following intriguing words: 'The Commission will be a political body. I want it to be an even more political body. It will be a highly politicised body. This could be viewed, in part, as a nod to his own Europarty heritage/connection as well as the party political make-up of the College of Commissioners (who themselves had to pass through Parliamentary hearings) that counts 14 members with an EPP affiliation, 8 from the PES, 5 from ALDE and 1 from the AECR. It may also be a prologue to Article 17(1) that calls upon the Commission to ' $\cdots$ initiate the Union's annual and multiannual programming with a view to achieving interinstitutional agreements'.

Ensuring the politicization of issues at the EU-level, though, is only half the story. There also needs to be corresponding EU-level representative vehicles in place that are capable of channelling those issues and representing those views. This is a role that can be played by those Europarties that wish to be part of a developing supranational democracy. As Külahci and Lightfoot put it, the Europarties are ' $\cdots$ at the centre of the potential democratization of European governance and their development is key to supranational representation.' Just prior to the 2014 European election, a new Party Regulation was approved. It will enter into force in 2017. At the time, EPP Rapporteur Marietta Giannakou (MEP) was quoted as saying: "The improvement of the rules on founding and funding EU political parties to increase their visibility, transparency and effectiveness are crucial..' While this undoubtedly represents another step in the forward evolution of the Europarties, one Europarty insider, nevertheless, was not quite so enamoured: 'We can live with the document but it's far from what we initially asked for. It 
does provide for a European status, however, how this will be ${ }_{35}$ ) practice remains to be seen since it is not a fully-fledged one.' For many advocates of the Europarties, the Holy Grail of reform remains the election of a small number of parliamentary seats via a single EUwide transnational list. Proponents believe this would provide a real showcase for the Europarties to prove that they are capable of selecting candidates and conducting a truly European-wide campaign. For Jo Leinen (MEP), speaking shortly after the 2014 election, ' $\cdots$ this would be the final breakthrough towards election campaigns and a European public space with European personalities and programmes - and a milestone for European democracy.'

\subsection{Concluding Remarks}

As we begin to digest the impact of the 2014 election, it seems as though in some quarters, at least, the aforementioned dilemma identified by Priestley is starting to be taken seriously. This has brought with it tentative signs of a shift of emphasis, on the part of the mainstream political forces at the EU-level, towards an emerging politicization that, to date, has manifested itself most overtly in the Spitzenkandidaten initiative - the goal of which was to help reinvigorate representative democracy at the EU-level. As an inaugural event, it is easy to point to some of its limitations and teething problems. These include the failure to generate the sort of ideological cut and thrust that some had hoped for, and the fact that, in the words of ALDE-Party President Graham $\underset{37}{W}$ ) in some countries it worked well $\cdots$ In other countries it bombed.' Despite these limitations, however, the Spitzenkandidaten initiative should be seen as an important milestone in the direction of politicizing the European elections and a success for the mainstream party political forces at the EU-level. This tentative shift may also manifest itself across the wider European project if the apparent intention of 
The 2014 European Parliamentary Elections: Emerging signs

of a shift from 'solidarity' to 'politicization' at the EU-level

(Day)

Commission President Juncker to have a 'highly politicized Commission' comes to fruition.

In contrast, when we look at the actual EP election results, mainstream forces, despite having secured some 70 percent of the parliamentary seats, find themselves on the back foot as the political momentum appears to side with their Eurosceptic foes. More generally, Eurosceptic success at the EU-level has contributed to their own version of a virtuous circle. Controversial statements generate media headlines that satisfy their political base/core supporters and create a powerful draw for potential voters during these unsettling times. This, in turn, has helped to create a political atmosphere where some of their views are having a not insignificant impact on domestic policy discourse. In the short-term, at least, it seems a safe bet to assume that notable national-level electoral advances lie ahead. At the EU-level, though, the biggest threat to their EPG and Europarty presence comes from within. Lacking the sort of organizational depth that can hold them together during times of intra-party upheaval such as a leadership conflict/change or periods of party fragmentation (usually emanating from within national delegations or as a result of conflict between national delegations) pose significant challenges. From that perspective, the group status of the EFDD looks particularly vulnerable. Precedent suggests that even if, or when, such groups are successful in forming a political group it will not be easy to maintain.

In the meantime, how might the mainstream respond if they wish to regain the political initiative? Part of the answer, of course, will begin to emerge during the 2014-2019 institutional cycle as we watch the unfolding relationship between the Commission and the Parliament. Will this new relationship be capable of producing outcomes that can tempt wavering voters away from Eurosceptic forces? Here the picture appears mixed. On the one hand, there are already claims that the Commission has been 'bruised and damaged' as a result of the spat between 
the Parliament and the European Council over the Spitzenkandidaten procedure as well as the controversy surrounding President Juncker and the tax arrangements of Luxembourg during his premiership. Yet, on the other hand, it is also necessary to ask whether the parliamentary mainstream, in general, and the EPP (both in its Europarty and EPG guise) in particular (the political family whence Juncker emerged), would be prepared to stand by and watch a lacklustre Commission give electoral succour to the political forces of Euroscepticism.

The elephant in the room for the mainstream, though, remains their national member parties and the amount of leeway that they are prepared to give to their corresponding Europarties and EPGs. Added to that, will national political parties, as members of the Europarties, be prepared to stress to national electorates that they are members of a wider European party family where they work with colleagues from other likeminded parties? In the short-to-medium term, support for the introduction of an EU-wide transnational list for the 2019 election seems unlikely, but not standing in the way of the Europarties (who will be operating under a new legal structure post-2017) as they seek to prepare for Spitzenkandidaten 2.0 seems much more realistic. Ultimately, however, unless the mainstream continues pursuing their own politicization, they are likely to give Eurosceptics, whose goal is to consolidate their anti-EU message into a highly salient electoral cleavage, a free hand in challenging the basis of the European project. For the moment, at least, it seems as if, to use the oft-used expression of football managers whose teams are one nil down at half time, "there is everything still to play for.'

* The foundations of this paper were laid as a result of invitations from Professor Ariyoshi Ogawa (Rikkyo University, March 25, 2014); Professor Takao Suami and Professor Tamio Nakamura (European Union Institute in Japan at Waseda University, 18 July 2014); Professor Machiko Hachiya (EUIJ-Kyushu Symposia, July 25, 2014); and Profes- 
The 2014 European Parliamentary Elections: Emerging signs

of a shift from 'solidarity' to 'politicization' at the EU-level

(Day)

sor Koji Fukuda (EUSA-Japan $35^{\text {th }}$ Congress, Rissho University, November. 8-9, 2014). I am extremely grateful for these opportunities and the thought-provoking comments from participants. I am also highly appreciative of the constructive comments from two anonymous referees. This paper forms part of a JSPS funded research project entitled 'Consolidating or Dismantling Representative Democracy at the EU-level'. KIBAN C 26380174. I would like to express my gratitude to the JSPS for their financial assistance. Any shortcomings are purely the fault of the author.

1) The EPGs are usually referred to as Party Groups or Political Groups. It is generally the case (though not always) that the national member parties (also known as national delegations) of an EPG are also members of the Groups corresponding Europarty. The Europarties, though, often have a wider membership that includes parties from beyond the EU-28 as well as, in recent years, various types of individual membership schemes. Although the EPGs and the Europarties are distinct - they play different roles in a parliamentary and extra-parliamentary setting - a lot of the media coverage about the election (especially the Spitzenkandidaten aspect of it) continued/ continues to conflate the two.

2 ) See for example Jeremy Rifkin, The European Dream: How Europe's Vision of the Future is Quietly Eclipsing the American Dream, Polity Press, 2004; and Mark Leonard, Why Europe Will Run the 21 ${ }^{\text {st }}$ Century, PublicAffairs, 2006.

3 ) Timothy Garton-Ash, 'Europe is torn between essential solidarity and national egoism', The Guardian, February 26, 2009.

4) Joschka Fischer, 'The erosion of Europe and its leadership crisis', Japan News, May 3, 2013, p. 11.

$5)$ Taken from Solidarity and Strength: The Future of the European Union, HeinrichBoll-Stiftung: Brussels, 2011, p. 7. In a similar vein, the European Liberals (ALDE) talk of the EU as 'a common project based on democracy, freedom and respect of human rights and, above all, solidarity.' Quoted in 'European Liberals and Democrats: Past and Present', ALDE-Party Employee Manual, 2007. Document held on file.

6) Julian Priestley, Six Battles that Shaped Europe's Parliament, London: John Harper Publishing, 2008, p. 207.

7 ) See, for example, the campaign video of the Alliance of European Conservatives and Reformists (AECR) entitled: There is No European Demos: Why AECR will not propose a candidate for the Commission Presidency. In the video, AECR Secretary-General, Daniel Hannan (MEP) claims that ' $\cdots$ that the European Commission will finally become a federal cabinet resting on the support of the European Parliament $\cdots$ We believe this process is setting up a government where there is no nation.' This is can be viewed at www.aecr.eu/aecr-to-not-field-candidate-for-commission-presidency/.

8) Here we can also include two of the smaller Europarties - the European Free Alli- 
『日本 $\mathrm{EU}$ 学会年報』第35号, 平成 27 年 4 月

ance (EFA) which is part of the EG/EFA Parliamentary Group and the European Democratic Party (EDP) whose MEPs sit with the ALDE-Group.

9) For a detailed insight into Euroscepticism as a concept and in operation at the national and European level, see 'Confronting Euroscepticism', Journal of Common Market Studies (Special Issue), Vol. 51, No. 1, 2013. For an interesting look at the differentiation across the Eurosceptic forces in the European Parliament see Christopher Alessi, 'Politically Fractured: Populists fail to shift EU balance', Der Spiegel Online Internation$a l$, November 18, 2013, as at http://www.spiegel.de/international/europe/populist-blocfails-to-change-agenda-in-european-politics-a-934268.html. Accessed February 15, 2014.

10) Quoted in 'Tsipras, Nominated by the European Left, as the Voice to Denounce the Policies of the Troika in the European Commission, Party of European Left Homepage, dated December 15, 2013, as at http://www.european-left.org/4th-el-congress/tsiprasnominated-european-left-voice-denounce-policies-troika-european-commission. Accessed October 15, 2014.

11) Stefan Goetze and Berthold Rittberger 'A matter of habit? The sociological foundations of empowering the European Parliament', Comparative European Politics, Vol. 8, No. 1, 2010, pp. 37-54. 46.

12) Eric Stein, 'The European Parliamentary Assembly: Techniques of Emerging "Political Control", International Organization, Vol. 13, No. 2, 1959, pp. 233-254. 237.

13) Karlheinz Reif and Hermann Schmitt, 'Nine Second Order National Elections: A Conceptual Framework for the Analysis of European Election Results', European Journal of Political Research, Vol. 8, No. 1, 1980, pp. 3-44. 9.

14) Richard Corbett, 'Wrong problems, flawed solution', Letter to the European Voice in response to an article by Charles Grant, October 31, 2013, p. 16.

15) At the time, Wallace believed that scenario 'precisely because the new European parliaments will have a vested interest in making the Parliament relevant to the EC as a whole and in forging more durable links with popular opinion.' Helen Wallace, 'Direct Elections and the Political Dynamics of the European Communities, Journal of Common Market Studies, Vol. XVII, No. 4, 1979, pp. 281-296. 293.

16) CSPEC, Report on the first direct elections of the European Parliament, 7-10 June 1979. Document held on file.

17) The procedural arrangement via which this took place stemmed from Article 251 EC (presently Article 224 TFEU). This necessitated input from the Council, EP and Commission (in conjunction with the five mainstream Europarties at that time) and would eventually culminate in the promulgation of the Party Regulation. See Regulation (EC) No 2004/2003 of the European Parliament and of the Council of 4 November 2003 on the regulations governing political parties at European level and the rules regarding their funding, OJ L 297, 15.11.2003, pp. 1-4. 
The 2014 European Parliamentary Elections: Emerging signs

of a shift from 'solidarity' to 'politicization' at the EU-level

(Day)

18) See Regulation (EC) No $1524 / 2007$ of the European Parliament and of the Council of 18 December 2007 amending Regulation (EC) No 2004/2003 on the regulations governing political parties at European level and the rules regarding their funding, OJ, L343, 27.12.2007, pp. 5-8. The budget for the Europarties in 2015 is $€ 28,350,084.15$ percent of the budget is divided equally amongst all the registered parties. The remainder is distributed on a proportional basis depending on the number of MEPs a Europarty has. Each of the Europarties also has a corresponding Political Foundation. The total budget for the foundations, using the same formula as for the Europarties, is $€ 13,668,000$. These figures come from the 2015 annual work programme of grants managed by the Directorate-General for Finance. Document held on file.

19) Joseph Weiler, 'Editorial - European Parliament Elections 2014: Europe's Fateful Choices', The European Journal of International Law, Vol. 24, No. 3, 2013, pp. 747-753. 751.

20) The measures that it asked for included: '1) before and during elections, national political parties should make clear to which European political party they are affiliated; 2 ) political parties should make known which candidate for President of the European Commission they support; 3 ) national parties should inform voters during the campaign about their candidate for President of the Commission.' See the press release by Viviane Reding '2014 European Parliament Elections: Commission recommends that political parties nominate candidates for Commission President', 12 March 2013, as at: http://ec.europa.eu/commission_2010-2014/reding/multimedia/news/2013/03/20130312_ en.htm. Accessed March 13, 2013.

21) Quoted in 'A stalking horse doing the EU few favours', European Voice, February 6, 2014.

22) Quoted in 'All change on the centre-left', European Voice, June 5, 2014, p. 6.

23) Quoted in 'European Elections: 'A bad day for the European Union' - Schulz', BBC News. com, May 26, 2014, as at http://www.bbc.com/news/world-europe-27572456. Accessed October 15, 2014.

24) 'Tsipras: Juncker should be first to seek majority for EC Presidency', Euronews, May 30, 2014, as at http://www.euronews.com/2014/05/30/tsipras-backs-juncker-for-theec-presidency/. Accessed July 2, 2014.

25) Toby Vogel, 'An exercise in democracy?', European Voice, June 5, 2014, p. 9.

26) European Council (2014) European Council. Conclusions June 26/27. EUCO 79/14. Document held on file.

27) Quoted in 'MEPs back Juncker's new "last-chance” commission', France 24. com, October 22, 2014, as at http://www.france24.com/en/20141022-eu-juncker-commission-parliament-approves-european/. Accessed December 20, 2014.

28) Quoted in 'Pope Warns EU of Voter Disillusionment After Debt Crisis', Bloomberg, 
『日本 $\mathrm{EU}$ 学会年報』第35号, 平成 27 年 4 月

November 25, 2014 as at http://www.bloomberg.com/news/2014-11-25/pope-warns-eu-ofvoter-disillusionment-after-debt-crisis.html. Accessed December 20, 2014.

29) Zielonka arrives at this outcome because he believes that: a) the default position of 'muddling through is unsustainable'; and b) 'the EU is unsuited to a federalist structure'. See Jan Zielonka 'The EU's future lies in devolving powers, not centralising them', Europe's World, Autumn 2014, pp. 57-59. 58.

30) Quoted in 'European Parliament should be abolished, says Jack Straw', The Guardian, February 21, 2012.

31) See Andreas Follesdal and Simon Hix, "Why There is a Democratic Deficit in the EU: A Response to Majone and Moravcsik', Journal of Common Market Studies, Vol. 44, No. 3, 2006, pp. 533-562. 557. The need for, and benefits of, enhanced politicization is a position that Professor Simon Hix (LSE) has been advocating for many years.

32) Quoted in 'Jean-Claude Juncker pledges to broaden EU capital markets', FT. com, July 15, 2014. Accessed December 20, 2014.

33) Erol Külahci and Simon Lightfoot, 'Governance, Europarties and the challenge of democratic representation in the EU: A case study of the Party of European Socialists', Acta Politica, Vol. 49, No. 1, January 2014, pp. 71-85. 71. Emphasis added.

34) Quoted in EPP Group in the European Parliament, Press Release, 'Statute and financing of European political parties', dated March 18, 2014, as at http://www.eppgroup.eu/press-release/Statute-and-financing-of-European-political-parties?usebuid=1346. Accessed December 20, 2014.

35) Correspondence with the author March 2014.

36) 'It's the parties, stupid! The Spinelli Group, July 1, 2014, as at http://www.spinelligroup.eu/article/its-parties-stupid. Accessed September 16, 2014.

37) These comments were made during a speech at the Party Congress of the ALDEParty, Lisbon, Portugal, November, 2014 which the author was in attendance. Another of those limitations included the fact that it was only mentioned by an average of 5 percent of voters as a reason for voting. However, there was a choice of seventeen possible reasons (including established reasons such as 'you always vote' or 'it is your duty to vote') out of which pollees were invited to select a maximum of three. See Directorate-General for Communication Public Opinion Monitoring Unit, 2014 Post-election Survey: European elections 2014 analytical overview, Brussels October 2014.

38) See 'Next Commission will start with its authority damaged', European Voice (editorial), June 19, 2014, p. 2. In the wake of the Luxembourg tax scandal Juncker felt that he had been weakened. See 'Juncker admits he is 'weaker' after fresh batch of Luxleaks revelations', EurActiv. com, October 12, 2014, as at http://www.euractiv.com/sections/eu-priorities-2020/juncker-admits-he-weakened-luxleaks-310704. Accessed December $20,2014$. 